\title{
PENGARUH SISTEM OLAH TANAH DAN PEMBERIAN HERBISIDA TERHADAP ALIRAN PERMUKAAN DAN EROSI PADA FASE GENERATIF PERTANAMAN SINGKONG (Manihot utilissima) MUSIM TANAM KE-2
}

\author{
Karina Rayyandini, Irwan Sukri Banuwa \& Afandi \\ Jurusan Agroteknologi Fakultas Pertanian Universitas Lampung \\ J1. Soemantri Brojonegoro No. 1, Bandar Lampung, Lampung 35145 \\ Email: rayyandini_karina@yahoo.com
}

\begin{abstract}
ABSTRAK
Degradasi lahan merupakan hilangnya fungsi tanah sebagai sumber air dan hara bagi tanaman, sebagai tempat akar tanaman berjangkar, serta sebagai tempat air dan unsur hara ditambahkan. Degradasi lahan dapat disebabkan oleh hilangnya unsur hara dan bahan organik dari daerah perakaran, terkumpulnya garam atau senyawa racun bagi tanaman di daerah perakaran, penjenuhan tanah oleh air (water logging), dan erosi. Aliran permukaan yang terjadi menjadi pemicu terjadinya erosi yang mengakibatkan degradasi lahan. Penelitian ini bertujuan untuk mengetahui pengaruh sistem olah tanah terhadap aliran permukaan dan erosi pada fase generatif tanaman singkong, untuk mengetahui pengaruh herbisida terhadap besarnya laju aliran permukaan dan erosi pada fase generatif tanaman singkong dan untuk mengetahui interaksi sistem olah tanah dan penggunaan herbisida terhadap aliran permukaan dan erosi pada fase generatif tanaman singkong. Penelitian ini dilakukan menggunakan metode petak kecil 4x4. Penelitian petak erosi ini menggunakan Rancangan Faktorial 2x2, dengan 4 kali ulangan. Perlakuan terdiri dari dua faktor yaitu sistem olah tanah dan herbisida. Hasil penelitian ini menunjukkan bahwa sistem olah tanah tidak nyata mempengaruhi aliran permukaan dan erosi, sedangkan herbisida nyata mempengaruhi aliran permukaan dan erosi yang terjadi. Penelitian ini dilakukan pada fase generatif pertanaman dan diperoleh 18 kali hujan dengan total curah hujan sebesar 477,2 $\mathrm{mm}$.
\end{abstract}

Kata kunci : Aliran permukaan, erosi, herbisida, sistem olah tanah

\section{PENDAHULUAN}

Olah tanah merupakan kegiatan memperbaiki kondisi tanah dengan proses pembalikan, penghancuran serta perataan tanah (Utomo, 2012). Olah tanah dapat memperbaiki infiltrasi air dan aerasi, dan mengendalikan hama serta sisa-sisa tanaman. Pengolahan tanah dapat meningkatan ketahanan tanah terhadap penetrasi gerakan vertikal air tanah atau yang lebih sering disebut daya infiltrasi tanah. Menurut Putte, dkk. (2012) aliran permukaan adalah air hujan atau bagian dari air hujan yang jatuh dan mengalir di atas permukaan tanah yang mengalir menuju daerah pengendapan seperti sungai, waduk atau laut. Aliran permukaan yang terjadi menjadi pemicu terjadinya erosi yang mengakibatkan degradasi lahan. Sistem olah tanah konservasi sangat diperlukan untuk menekan besarnya aliran permukaan dan erosi (Banuwa, 2013). Menurut Meijer, dkk. (2013) pengolahan tanah secara signifikan dapat mempengaruhi kerentanan tanah terhadap erosi yang dapat mempercepat dan memperbesar laju erosi.

Erosi menyebabkan hilangnya tanah lapisan atas yang mempunyai sifat fisik dan kimia yang baik (Schmidt,
2000). Hal ini mengakibatkan terjadinya degradasi lahan, yang merupakan hilangnya fungsi tanah sebagai sumber air dan hara bagi tanaman, sebagai tempat akar tanaman berjangkar, serta sebagai tempat air dan unsur hara ditambahkan. Degradasi lahan dapat disebabkan oleh hilangnya unsur hara dan bahan organik dari daerah perakaran, terkumpulnya garam atau senyawa racun bagi tanaman di daerah perakaran, penjenuhan tanah oleh air (water logging), dan erosi (Arsyad, 2010).

Penyebab terjadinya erosi tentu tidak lepas dari peranan manusia terutama ditinjau dari tindakan dalam memperlakukan lahan untuk memenuhi kebutuhannya. Tindakan manusia yang hanya semata-mata untuk mendapatkan keuntungan tanpa menjaga keseimbangan alam dan lingkungannya akan menjadi penyebab meningkatnya erosi (Banuwa, 2013). Manusia juga dapat mencegah atau menekan erosi dengan tindakan pengelolaan lahan yang mempertimbangkan keseimbangan antara kerusakan tanah dengan proses pembentukan tanah. Dalam hal ini manusia mengelola lahan sesuai dengan kemampuan tanah dan mencegah terjadinya kerusakan tanah tersebut (Arsyad, 2010). 
Vegetasi di atas tanah atau tumbuhan yang tumbuh diatas permukaan tanah memiliki pengaruh dalam mencegah aliran permukaan dan erosi (Arsyad, 2010). Salah satu cara untuk mengurangi aliran permukaan yang terjadi, dapat dilakukan dengan teknik budidaya tanaman vegetasi dan pemanfaatan sisa tanaman atau serasah. Vegetasi (penutup tanah) dapat berupa bagian tanaman atau gulma. Penutupan tanah oleh vegetasi dapat menurunkan aliran permukaan yang terjadi, sehingga erosi menjadi berkurang (Schmidt, 2000).

Herbisida adalah bahan kimia atau kultur hayati yang dapat menghambat pertumbuhan atau mematikan gulma (Sembodo, 2010). Penggunaan herbisida bahan aktif glyfosat sangat efektik dalam memberantas gulma dalam waktu singkat. Bahan aktif 2,4 D pada herbisida juga dapat mengendalikan gulma dengan baik karena bersifat efektif, selektif dan sistemik. Aplikasi herbisida dapat mengurangi gulma yang berperan sebagai vegetasi (Lamid, dkk. 1998).

\section{BAHAN DAN METODE}

Penelitian ini dilaksanakan di Laboratorium Lapang Terpadu Fakultas Pertanian Universitas Lampung. Penelitian ini merupakan penelitian tahun ke3 dan hanya dilakukan pada fase generatif pertanaman singkong yaitu bulan April sampai dengan Oktober 2016. Untuk menghitung aliran permukaan dan erosi yang terjadi.

Penelitian ini dilaksanakan pada petak erosi dan menggunakan rancangan faktorial $2 \times 2$ dengan 4 kali ulangan. Faktor pertama meliputi Sistem Olah Tanah, yakni $\mathrm{F}$ (pengolahan tanah penuh/konvensional) dan $\mathrm{M}$ (pengolahan tanah minimum), dan faktor kedua meliputi Herbisida yakni H1 (pemberian herbisida), H0 (tanpa pemberian herbisida). Sehingga didapatkan 16 perlakuan (Gambar 1).

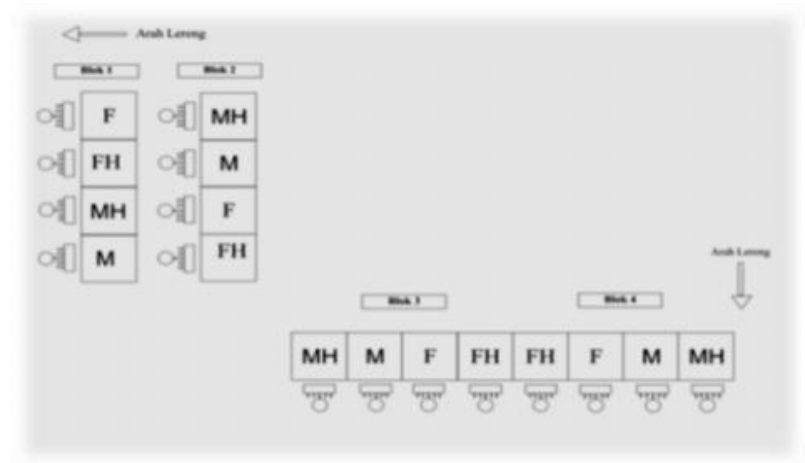

Gambar 1. Skema penelitian pada petak erosi.

\section{HASIL DAN PEMBAHASAN}

Hasil penelitian menunjukkan bahwa perlakuan olah tanah nyata mempengaruhi bobot gulma pertanaman dan bobot brangkasan tanaman singkong, namun tidak nyata mempengaruhi laju erosi dan aliran permukaan tanah, diameter singkong, tinggi singkong, serta produksi singkong. Perlakuan herbisida nyata mempengaruhi laju erosi, aliran permukaan, serta diameter dan tinggi tanaman singkong. Perlakuan herbisida tidak nyata mempengaruhi bobot gulma, serta bobot brangkasan dan produksi singkong. Interaksi perlakuan olah tanah dan pemberian herbsida tidak nyata mempengaruhi seluruh variabel yang diamati. Hasil penelitian yang telah dilakukan ini diperoleh 18 kali hujan dengan total curah hujan yang terjadi sebesar 477,2 mm. Pada perhitungan diperoleh kadar air tanah sebesar 0,94 gram. Aliran permukaan dan erosi yang terjadi nyata dipengaruhi oleh perlakuan herbisida.

Aliran Permukaan (mm). Berdasarkan data yang diperoleh dan kemudian dilakukan uji BNT (Tabel 1), dari total curah hujan yang didapat yaitu sebesar 477,2 $\mathrm{mm}$, hanya $7 \%$ yang menimbulkan aliran permukaan pada perlakuan pemberian herbisida. Pada perlakuan $\mathrm{F}$ yaitu $6,7 \%$, pada perlakuan $M$ yaitu $5,1 \%$, dan yang terendah pada perlakuan tanpa herbisida yaitu $5 \%$. Menurut Troeh (dkk, 1980 dalam Banuwa 2013) aliran permukaan dapat mencapai $75 \%$ dari hujan pada tanah yang tidak permeabel, lereng curam dan kondisi vegetasi yang buruk.

Pada dasarnya perlakuan olah tanah penuh sangat berbeda dengan perlakuan olah tanah minimum. Perlakuan olah tanah minimum dilakukan dengan tujuan memperkecil aliran permukaan dan erosi. Pada perlakuan olah tanah minimum, aliran permukaan yang terjadi lebih kecil daripada perlakuan olah tanah penuh. Karena pada olah tanah minimum, tanah hanya diolah seperlunya dengan meninggalkan sisa tanaman sebagai mulsa. Sedangkan pada perlakuan olah tanah penuh, tanah diolah secara maksimal tanpa memanfaatkan sisa tanaman dan gulma sebagai penutup tanah, sehingga aliran permukaannya tinggi.

Erosi. Hasil pengamatan yang didapat berbeda dari tujuan olah tanah minimum yang dilakukan. Erosi yang terjadi pada perlakuan olah tanah minimum memiliki jumlah yang sama dengan erosi yang terjadi pada perlakuan olah tanah penuh yaitu sebesar 0,09 ton/ ha. Hal ini diduga karena produksi yang didapat (Tabel 2) berpengaruh terhadap aliran permukaan dan erosi yang terjadi. Pertumbuhan umbi di lahan pertanaman pada fase generatif dapat memecah agregat tanah dan merubah struktur tanah. Umbi yang terdapat di dalam 
Tabel 1. Pengaruh Olah Tanah dan Herbisida terhadap Aliran Permukaan

\begin{tabular}{cc}
\hline Perlakuan & Aliran Permukaan $(\mathrm{mm})$ \\
\hline F & $32,88 \mathrm{a}$ \\
M & $24,64 \mathrm{a}$ \\
\hline H0 & $23,90 \mathrm{a}$ \\
H1 & $33,63 \mathrm{~b}$ \\
\hline Nilai BNT & 8,76
\end{tabular}

Keterangan : $\mathrm{F}=$ olah tanah penuh, $\mathrm{M}=$ olah tanah minimum, $\mathrm{H} 0=$ tanpa herbisida, $\mathrm{H} 1=$ pemberian herbisida. Nilai tengah pada gambar yang diikuti oleh huruf yang sama tidak berbeda nyata berdasarkan Uji BNT pada taraf 5\%.

Tabel 2. Pengaruh Olah Tanah dan Herbisida terhadap Erosi

\begin{tabular}{cc}
\hline Perlakuan & Erosi (Ton/ha) \\
\hline F & $0,09 \mathrm{a}$ \\
M & $0,09 \mathrm{a}$ \\
\hline H0 & $0,08 \mathrm{a}$ \\
H1 & $0,11 \mathrm{~b}$ \\
\hline Nilai BNT & 0,03
\end{tabular}

Keterangan : $\mathrm{F}=$ olah tanah penuh, $\mathrm{M}=$ olah tanah minimum, $\mathrm{H} 0=$ tanpa herbisida, $\mathrm{H} 1=$ pemberian herbisida. Nilai tengah pada gambar yang diikuti oleh huruf yang sama tidak berbeda nyata berdasarkan Uji BNT pada taraf 5\%.

tanah semakin lama akan semakin besar dan akan mengangkat permukaan tanah. Oleh karena itu seiring berjalannya waktu, pada lahan perlakuan olah tanah minimum dan olah tanah penuh memperoleh erosi yang sama besar.

Selain itu, ada atau tidaknya bahan pembawa erosi yang semakin lama semakin berkurang dapat mempengaruhi besarnya erosi yang terjadi. Menurut Arsyad (2010) pengolahan tanah hanya memperbaiki sifat fisik tanah sementara, karena tanah yang telah diolah akan lebih mudah terangkat oleh air. Menurut Banuwa (2013) Erosi tanah terjadi melalui proses penghancuran partikel-partikel tanah dan proses pengangkutan partikel-partikel tanah yang telah dihancurkan. Terdapat dua macam erosi yang terjadi yaitu erosi percik (splash erosion) merupakan erosi yang disebabkan oleh pemecahan struktur tanah dan erosi gerusan (scour erosion) merupakan erosi yang disebabkan oleh gerusan aliran permukaan.

Pengaruh pertumbuhan umbi yang memecah agregat tanah dapat memperbesar terjadinya erosi percik. Erosi percik ini akan semakin besar dengan semakin besarnya massa dan kecepatan jatuh butir hujan (Arsyad, 2010). Erosi disebabkan oleh aliran permukaan yang dipengaruhi oleh beberapa faktor curah hujan, karakteristik tanah (sifat fisik), penutupan lahan, dan kemiringan lereng.
Pemberian herbisida mampu mengendalikan gulma di lahan. Pemberian herbisida menyebabkan berkurangnya persen penutupan tanah oleh tanaman. Berkurangnya penutup tanah akan menyebabkan infiltrasi menurun yang mengakibatkan aliran permukaan tinggi. Gulma di lahan selain dapat meningkatkan infiltrasi, juga dapat menjadi penghalang terbawanya partikel tanah oleh air yang dapat menimbulkan erosi. Air hujan yang jatuh ke permukaan tidak lagi dihambat oleh keberadaan gulma yang berfungsi sebagai tanaman vegetasi sehingga tanah lebih mudah terangkut dan terbawa oleh air.

Menurut Schwab, dkk (1981 dalam Banuwa 2013) vegetasi yang baik akan memperlambat aliran permukaan dan akan meningkatkan infiltrasi untuk mengurangi laju aliran permukaan yang akan menimbulkan erosi. Pada perlakuan tanpa herbisida, aliran permukaan dan erosi paling kecil terjadi. Hal ini dikarenakan keberadaan gulma di lahan berfungsi sebagai penutup tanah yang dapat mengurangi aliran permukaan.

Hasil penelitian ini sejalan dengan hasil penelitian Banuwa, dkk. (2014) bahwa pengolahan tanah tidak nyata mempengaruhi aliran permukaan yang terjadi. Aliran permukaan dan erosi memiliki hubungan erat dengan curah hujan, karena air hujan yang jatuh ke permukaan tanah dapat mengangkut tanah lapisan atas 
yang disebabkan oleh aliran permukaan. Menurut Sutedjo dan Kartasapoetra (2002) curah hujan merupakan salah satu unsur iklim yang besar perannya terhadap kejadian longsor dan erosi.

Menurut Wischmeir dan Smith (1978 dalam Banuwa, 2013) curah hujan mempengaruhi erosi dengan dua cara yaitu pukulan butir hujan terhadap tanah serta jumlah dan lamanya hujan.

Aliran permukaan terjadi pada saat butir hujan jatuh diatas permukaan tanah, butir hujan ini yang dapat memecahkan agregat tanah menjadi partikel kecil. Sehingga partikel tersebut akan mengikuti infiltrasi tanah dan akan menyumbat pori-pori tanah. Jumlah dan lamanya hujan inilah yang akan menentukan besarnya erosi. Dalam hal ini hujan yang jatuh ke permukaan akan mempengaruhi aliran permukaan, dan aliran permukaan tersebut berpengaruh besar terhadap keterjadian suatu erosi. Apabila curah hujan tinggi maka aliran permukaan meningkat dan mengakibatkan erosi meningkat.

Dariah, dkk. (2003) mengatakan bahwa air hujan yang jatuh di atas permukaan tanah dan menjadi air limpasan permukaan merupakan penyebab utama terjadinya erosi. Hujan dengan curah hujan dan intensitas yang tinggi, contohnya $50 \mathrm{~mm}$ dalam waktu kurang dari 1 jam lebih berpotensi menyebabkan erosi dibandingkan hujan dengan curah hujan yang sama namun dalam waktu yang lebih lama atau lebih dari 1 jam. Intensitas hujan menentukan aliran permukaan yang mampu menimbulkan erosi.

Erosi menyebabkan tanah lapisan atas terkikis dan mengangkut unsur hara yang terkandung didalamnya, apabila erosi terus terjadi maka unsur hara akan semakin menurun. Hal ini menyebabkan produksi tanaman akan menurun. Menurut Banuwa (2013) erosi secara terus menerus akan menimbulkan dampak pada tempat kejadian erosi. Dampak erosi yang ditimbulkan yaitu menurunnya kesuburan tanah, menurunnya kualitas sifat fisik tanah, menurunnya kapasitas infiltrasi dan menurunnya produktivitas lahan pertanian.

Pertumbuhan Tanaman. Pengamatan pertumbuhan tanaman yang dilakukan meliputi diameter batang dan tinggi tanaman singkong. Berdasarkan uji BNT dari hasil perhitungan, terlihat pada (Tabel 3) diameter batang tertinggi dipengaruhi oleh perlakuan pemberian herbisida sebesar $2,94 \mathrm{~cm}$. Sedangkan pada perlakuan tanpa herbisida, diameter batang yang diperoleh paling rendah yaitu sebesar $2,55 \mathrm{~cm}$. Perlakuan olah tanah minimum dan olah tanah penuh memperoleh rata-rata diameter batang yang tidak jauh berbeda yaitu $2,71 \mathrm{~cm}$ dan $2,77 \mathrm{~cm}$. Untuk tinggi tanaman (Tabel 4) pada perlakuan pemberian herbisida juga jauh lebih tinggi yaitu sebesar $410 \mathrm{~cm}$, daripada perlakuan tanpa herbisida. Sedangkan perlakuan olah

Tabel 3. Pengaruh Olah Tanah dan Herbisida terhadap Diameter Batang

\begin{tabular}{cc}
\hline Perlakuan & Diameter Batang $(\mathrm{cm})$ \\
\hline $\mathrm{F}$ & $2,71 \mathrm{a}$ \\
$\mathrm{M}$ & $2,77 \mathrm{a}$ \\
\hline $\mathrm{H} 0$ & $2,55 \mathrm{a}$ \\
$\mathrm{H} 1$ & $2,94 \mathrm{~b}$ \\
\hline Nilai BNT & 0,28 \\
\hline
\end{tabular}

Keterangan $: \mathrm{F}=$ olah tanah penuh, $\mathrm{M}=$ olah tanah minimum, $\mathrm{H} 0=$ tanpa herbisida, $\mathrm{H} 1=$ pemberian herbisida. Nilai tengah pada gambar yang diikuti oleh huruf yang sama tidak berbeda nyata berdasarkan Uji BNT pada taraf 5\%.

Tabel 4. Pengaruh Olah Tanah dan Herbisida terhadap Tinggi Tanaman

\begin{tabular}{cc}
\hline Perlakuan & Tinggi tanaman $(\mathrm{cm})$ \\
\hline F & $393,35 \mathrm{a}$ \\
M & $390,45 \mathrm{a}$ \\
\hline H0 & $373,80 \mathrm{a}$ \\
H1 & $410,00 \mathrm{~b}$ \\
\hline Nilai BNT & 29,44
\end{tabular}

Keterangan : $\mathrm{F}=$ olah tanah penuh, $\mathrm{M}=$ olah tanah minimum, $\mathrm{H} 0=$ tanpa herbisida, $\mathrm{H} 1=$ pemberian herbisida. Nilai tengah pada gambar yang diikuti oleh huruf yang sama tidak berbeda nyata berdasarkan Uji BNT pada taraf 5\%. 
tanah masing-masing tinggi tanaman tidak jauh berbeda yaitu F sebesar 393,35 cm dan M sebesar 390,45 cm.

Hasil penelitian ini sejalan dengan Jamila (2007) yang menyatakan bahwa pengolahan tanah, mulsa, maupun interaksi keduanya tidak nyata mempengaruhi tinggi tanaman kedelai. Namun pemberian herbisida nyata mempengaruhi diameter dan tinggi tanaman singkong. Pada perlakuan pemberian herbisida, menyebakan gulma pada lahan berkurang, sehingga mengurangi persaingan perebutan unsur hara, cahaya, dan air antara tanaman budidaya dan gulma. Oleh karena itu pertumbuhan tanaman (diameter batang dan tinggi tanaman) pada lahan perlakuan pemberian herbisida lebih baik dibandingkan perlakuan lainnya.

Gulma. Hasil perhitungan pada (Tabel 5) menunjukkan bahwa, keberadaan gulma tertinggi terdapat pada lahan perlakuan olah tanah minimum sebesar 5,43 ton/ha, sedangkan pada perlakuan olah tanah penuh hanya terdapat gulma sebesar 3,36 ton/ha.

Menurut Arsyad (2010) peran tanaman penutup tanah antara lain: (1) intersepsi hujan oleh tajuk tanaman (2) menahan atau mengurangi daya perusak butir-butir hujan yang jatuh dan aliran air di atas permukaan tanah, (3) menambah bahan organik tanah serta pengaruh akar dan kegiatan biologi, (4) melakukan transpirasi, yang mengurangi kandungan air tanah, dan (5) mempengaruhi stabilitas struktur dan porositas tanah. Peranan tanaman penutup tanah tersebut menyebabkan berkurangnya kekuatan dispersi air hujan, mengurangi jumlah serta kecepatan aliran permukaan dan memperbesar infiltrasi air ke dalam tanah, sehingga dapat mengurangi erosi.

Brangkasan Tanaman. Perlakuan olah tanah penuh memperoleh brangkasan tanaman (Tabel 6) paling tinggi yaitu sebesar 58,20 ton/ha. Sedangkan perlakuan olah tanah minimum memperoleh brangkasan tanaman paling rendah yaitu sebesar 43,59 ton/ha.

Produksi. Terlihat pada (Tabel 7) bahwa masingmasing perlakuan memperoleh produksi tanaman singkong F (olah tanah penuh) sebesar 43,75 ton/ha, M (olah tanah minimum) sebesar 43,28 ton/ha, H0 (tanpa herbisida) sebesar 42,97 ton/ha, dan H1 (dengan herbisida) sebesar 44,06 ton/ha. Produksi yang didapatkan ini cukup baik dalam rata-rata jumlah produksi per hektar. Direktur Pascapanen Tanaman Pangan Kementerian Pertanian menilai target produksi singkong di tingkat petani adalah sekitar 40-60 ton/ha. Angka ini menunjukkan bahwa produksi yang didapat telah sesuai dengan target produksi rata-rata di Indonesia. Artinya, aliran permukaan dan erosi yang terjadi tidak mempengaruhi pertumbuhan tanaman singkong sehingga produksi tetap tinggi. Hal ini dimungkinkan karena jumlah erosi yang tidak terlalu besar dalam setiap petak, serta adaanya peran tanaman vegetasi dalam menghambat aliran permukaan.

Tabel 5. Pengaruh Olah Tanah dan Herbisida terhadap Gulma

\begin{tabular}{cc}
\hline Perlakuan & Berat Basah Gulma (Ton/ha) \\
\hline F & 3,36 a \\
M & $5,43 \mathrm{~b}$ \\
\hline H0 & 4,73 a \\
H1 & 4,06 a \\
\hline Nilai BNT & 1,96 \\
\hline
\end{tabular}

Keterangan : $\mathrm{F}=$ olah tanah penuh, $\mathrm{M}=$ olah tanah minimum, $\mathrm{H} 0=$ tanpa herbisida, $\mathrm{H} 1$ = pemberian herbisida. Nilai tengah pada gambar yang diikuti oleh huruf yang sama tidak berbeda nyata berdasarkan Uji BNT pada taraf 5\%.

Tabel 6. Pengaruh Olah Tanah dan Herbisida terhadap Brangkasan

\begin{tabular}{cc}
\hline Perlakuan & Brangkasan Tanaman (Ton/ha) \\
\hline F & $58,20 \mathrm{~b}$ \\
M & $43,59 \mathrm{a}$ \\
\hline H0 & $47,66 \mathrm{a}$ \\
H1 & $54,14 \mathrm{a}$ \\
\hline Nilai BNT & 11,18
\end{tabular}

Keterangan : $\mathrm{F}=$ olah tanah penuh, $\mathrm{M}=$ olah tanah minimum, $\mathrm{H} 0=$ tanpa herbisida, $\mathrm{H} 1=$ pemberian herbisida. Nilai tengah pada gambar yang diikuti oleh huruf yang sama tidak berbeda nyata berdasarkan Uji BNT pada taraf 5\%. 
Tabel 7. Pengaruh Olah Tanah dan Herbisida terhadap Produksi

\begin{tabular}{cc}
\hline Perlakuan & Produksi (Ton/ha) \\
\hline F & $43,75 \mathrm{a}$ \\
M & $43,28 \mathrm{a}$ \\
\hline H0 & $42,97 \mathrm{a}$ \\
H1 & $44,06 \mathrm{a}$ \\
\hline Nilai BNT & 7,87
\end{tabular}

Keterangan $: \mathrm{F}=$ olah tanah penuh, $\mathrm{M}=$ olah tanah minimum, $\mathrm{H} 0=$ tanpa herbisida, $\mathrm{H} 1=$ pemberian herbisida. Nilai tengah pada gambar yang diikuti oleh huruf yang sama tidak berbeda nyata berdasarkan Uji BNT pada taraf 5\%.

\section{KESIMPULAN}

Dari hasil penelitian, dapat disimpulkan bahwa perlakuan olah tanah tidak nyata mempengaruhi aliran permukaan, erosi, pertumbuhan dan produksi tanaman singkong. Tetapi nyata mempengaruhi gulma dan brangkasan tanaman singkong. Perlakuan pemberian herbisida berpengaruh nyata meningkatkan aliran permukaan dan erosi yang terjadi. Tetapi tidak nyata mempengaruhi produksi tanaman singkong. Tidak terdapat interaksi antara perlakuan olah tanah dengan penggunaan herbisida terhadap aliran permukaan dan erosi serta variabel lainnya pada pertanaman singkong.

\section{DAFTAR PUSTAKA}

Arsyad, Sitanala. 2006. Konservasi Tanah dan Air. Penerbit IPB (IPB Pers). Bogor.

Banuwa, I.S. 2013. Erosi. Kencana Prenada Media Group. Jakarta. $205 \mathrm{hlm}$.

Banuwa, I.S., Andhi, U. Hassanudin, and K. Fujie. 2014. Erosion and Nutrien Enrichment Under Diferrent Tillage and Weed Control Systems. 9th IWA International Symposium on Waste Management Problems in Agro-Industries. Kochi, Japan: 24-26 November.

Bowman, M.T., P.A. Beck, K. S. Lusby, S.A. Gunter, and D.S. Hubbell. 2005. No-till, Reduced Tillage, and Conventional Tillage Systems for Small-grain Forage Production. Arkansas Animal Science Department Report. Ark. Agri. Exp. Stat. Res. Series 535: 80-82.

Dariah, A., F. Agus, S. Arsyad, Sudarsono, dan Maswar. 2003. Erosi dan Aliran Permukaan pada Lahan Pertanian Berbasis Tanaman Kopi di Sumberjaya, Lampung Barat. Jurnal Agrivista, 26 (1): 5260.
Fakihhudin, M.Danang. 2014. Penggunaan Herbisida IPA-Glifosat terhadap Pertumbuhan, Hasil dan Residu pada Jagung. Jurnal Ilmu Pertanian. Vol. 17 No. 1.

Jamila., Kaharuddin. 2007. Efektivitas Mulsa dan Sistem Olah Tanah terhadap Produktivitas Tanah Dangkal dan Berbatu untuk Produksi Kedelai. Jurnal Agrisistem, 3 (2): 65-75.

Kartasapoetra, G., A.G. Kartasapoetra, M.M. Sutedjo. 2010. Teknologi Konservasi Tanah dan Air Edisi Kedua. PT Rineka Cipta. Jakarta. 194 hlm.

Meijer, A.D., J.L. Heitman, J.G. White, and R.E. Austin. 2013. Measuring Erosion in Long Term Tillage Plots Using Grounds Based Lidar. Journal Soil and Erosion, 126: 1-10.

Putte, A.V.D., G. Govers, J. Diels, C. Langhans, W. Clymans, E. Vanuytrecht, R. Merckx, and D. Raes. 2012. Soil Functioning and Conservation Tillage in Belgian Loam Belt. Journal Soil and Tillage Research, 122: 1-11.

Schmidt, Jurgen. 2000. Soil Erosion. Springer-Verlag Berlin Heidlberg. Germany.

Sembodo, D. 2010. Gulma dan Pengelolaannya. Graha Ilmu. Yogyakarta.

Suwardjo. 1981. Peranan Sisa-Sisa Tanaman dalam Konservasi Tanah dan Air pada Usahatani Tanaman Semusim. Disertasi FPS IPB. Bogor.

Utomo, M., H. Buchari., I.S. Banuwa. 2012. Olah Tanah Konservasi: Teknologi Mitigasi Gas Rumah Kaca Pertanian Tanaman Pangan. Lembaga Penelitian Universitas Lampung. Bandar Lampung. 94 Halaman.

Utomo, M. 2012. Tanpa Olah Tanah: Teknologi Pengelolaan Pertanian Lahan Kering. Lembaga Penelitian Universitas Lampung. Bandar Lampung. 110 Halaman. 